\title{
THE USE OF A SIMULATION MODEL TO ANALYZE THE IMPACT OF HEAVY TRANSPORT GENERATED BY THE PORT TO THE CITY TRAFFIC.
}

\section{WYKORZYSTANIE MODELU SYMULACYJNEGO DO ANALIZY WPLYWU TRANSPORTU CIEŻKIEGO GENEROWANEGO PRZEZ PORT NA RUCH MIEJSKI}

\author{
Natalia Stasiak, Leszek Smolarek \\ Gdynia Maritime University, Akademia Morska w Gdyni
}

\begin{abstract}
The article presents an analysis of the impact of transport on heavy urban traffic on Wharf Kwiatkowski using program PTV Vissim. The data for analysis were taken from the Road and Greenery in Gdynia from program PTV Visum. Attention has been focused on vehicle traffic in the afternoon the top of its intensity. Model of Kwiatkowskiego Wharf, made entirely in the PTV VISSIM, was used for microscopic simulation of traffic. With its help, it was possible to find and analyze the behavior of each autonomous vehicle and interactions on the Web. For the analysis was used as a program of traffic lights currency at these junctions. The analysis results of simulation in the PTV VISSIM are related to the movement of the two structures. The first assumes that the route will move cars and trucks, taking into account their share in the network based on the intensity of traffic during peak hours of the afternoon, the second consisted only of cars. The results presented are based on measuring the time of travel and delays on specific relationships and the average length of queues at selected inlets. The results of analysis and simulation tests were subjected to statistical analysis.
\end{abstract}

Keywords: traffic analysis, simulation model

Streszczenie: $W$ artykule przedstawiona zostata analiza oddziaływania transportu ciężkiego na ruch miejski na Estakadzie Kwiatkowskiego z zastosowaniem programu PTV Vissim firmy PTV AG. Dane do wykonania analizy zostały uzyskane $z$ Zarzadu Dróg $i$ Zieleni w Gdyni. Analiza dotyczyła ruchu pojazdów $w$ popotudniowym szczycie jego natężenia $w$ aspekcie oddziatywania ruchu pojazdów ciężkich. $W$ badaniach zastosowano model symulacyjny wykonany w programie PTV Vissim. Model Estakady Kwiatkowskiego stużt do mikroskopowej symulacji ruchu drogowego. Za jego pomoca, możliwe byto znalezienie i przeanalizowanie zachowania każdego autonomicznego pojazdu jak $i$ interakcji zachodzacych $w$ sieci. Do wykonania analizy zostat uzyty program sygnalizacji świetlnej obowiązujacy na poszczególnych skrzyżowaniach.

Stowa kluczowe: analiza ruchu, model symulacyjny 
The use of a simulation model to analyze the impact of heavy transport ... Wykorzystanie modelu symulacyjnego do analizy wplywu transportu...

\section{Introduction}

Kwiatkowski's Wharf is a fast-track route in Gdynia connecting Ferry and Container Ports, a shipyard and naval base with the Tri-City bypass and the A1 motorway. Kwiatkowski Wharf is a direct connection serving the traffic of heavy vehicles between the developing port and the roads for wheeled cargo transportation. Its construction began on 30 August 1974 and ended on 12 June 2008. This route is the longest and most noticeable section of many places in Gdynia [1]. The purpose of the study was to determine whether the heavy transport generated by the ports in Gdynia significantly affects the traffic on the Kwiatkowski Wharf, especially during times of increased passenger traffic.

The modelled area concerned:

- for the first measurement of the section of Kwiatkowski Wharf from the TriCity Ring Road to the intersection at the end of Kwiatkowski Wharf (before Dąbka Street);

- For the second measurement, the section from the entrance from Janka Wiśniewskiego Street to the intersection at the end of Kwiatkowski Wharf (before Dąbka Street).

In the created simulation model, traffic flows from the following directions were included:

- Oksywie, Stare Obłuże - st. Dąbka;

- Navy Yard, Pogórze, BCT in Gdynia - st. Unruga st. Kontenerowa;

- Stena Line Terminal in Gdynia - st. Promowa;

- GCT - st. Gołębia, st. Janka Wiśniewskiego;

- Center of Gdynia - st. Janka Wiśniewskiego, st. Morska;

- Rumia - st. Hutnicza;

- Gdynia Chylonia - st. Morska;

- Tricity Bypass.

\section{Simulation model of the investigated system}

The Vissim program is used for microscopic traffic simulations in motion modeling. With it, it is possible to find and analyze the various traffic generation solutions. Microscopic models describe separately the behavior of each autonomous vehicle in the network, so both the elements of the transport system and the interactions in the network are presented in great detail. With the help of the VISSIM program, you can analyze the traffic conditions of individual and collective traffic, including factors such as the impact of bus stops, pedestrian crossings, traffic patterns, and more.

The VISSIM package includes two different internal programs: a motion simulator and a signal generator. The first of the programs collects data from the detectors and controls the signaling, and the other is a microscopic motion simulator containing the Wiederman principle of "driving behind the leader" [2]. It assumes that drivers are responding to changes in the driving behavior of vehicles preceding [3]. This is a psychophysical model of vehicle behavior in motion developed by Wiedemann, which assumes that the driver of the moving vehicle starts to brake faster when he reaches his individual perception threshold of the vehicle that moves more slowly. 
However, it is not able to determine the speed of this vehicle unequivocally, so it brakes until its speed is even lower and then accelerates. Consequently, this leads to braking and acceleration. Other less accurate programs use constant vehicle velocity to compute [4]. In addition, the motion model simulator takes into account situations such as the prioritization of two adjacent vehicles on adjacent lanes on a multi-lane road, but also assumes that, at a distance of $100 \mathrm{~m}$ from the traffic signal, the attention of the driver is increased. All these factors combined with the exact Wiedemann model make the VISSIM motion simulator very accurate.

The Wiedeman model used in the program describes the boundary between the distinctive states that are: free riding, approaching, dependent driving, braking. Measurement times in PTV VISSIM allow you to calculate the flow time of a vehicle traffic stream in a given configuration. To examine the impact of heavy transport generated by the Gdynia ports on the Kwiatkowski Wharf, two options have to be taken into account and compiled. Namely, the first variant assumed the assumption that the time of passage of passenger cars is calculated for the case of participation in truck and passenger traffic. In the second, the exclusion of passenger cars from the Kwiatkowski Route. As for the unit of measurement time, it was modeled two hours. However, the results were measured for half an hour, since the previous period served to fill the entire network with vehicles. The Friday afternoon peak was examined, 14-16 hours. The program required to define driving times on the road network. Connections have been selected in such a way as to show the effects of vehicles in terms of total generic structure (trucks and cars) and detailed (passenger cars only) during transport and queues. In addition, the simulation was performed in such a way as to see changes across the entire network, not just on specific routes.

In order to obtain data, two measurement times were taken into account, allowing us to assess whether the heavy transport generated by the ports in Gdynia significantly affects the traffic on the Kwiatkowski Estuary. They will be marked respectively No. 1 and No. 2. Measurement for 1 time of travel will be reported in relation: Kwiatkowskiego Wharf (from the side of the Tri-City Ring Road) Crossroads at the end of Kwiatkowski Wharf (before Dąbka street). The second measurement will be set from Janka Wiśniewskiego Street to the same point as above. The first route was selected to check the overall time of the vehicle traveling through the network, and the second route contains the largest percentage of lorries across the entire network, and therefore its importance will be important. The measurement time was taken into account with the generators on the Kwiatkowski Route.

The individual numbers are in the first column in Tables 1 and 2 .

They indicate the specific entry points:

1. st. Dąbka (from Oksywie);

2. st. Dąbka (from Stare Obłuże); 
The use of a simulation model to analyze the impact of heavy transport ... Wykorzystanie modelu symulacyjnego do analizy wplywu transportu...

3. st. Unruga (from Naval Yard);

4. st. Unruga (from Pogórze);

5. st. Kontenerowa (from BCT in Gdynia);

6. st. Kontenerowa (from Pogórze);

7. st. Promowa (from Stena Line Terminal In Gdynia);

8. st. Gołębia (from GCT);

9. st. Janka Wiśniewskiego (from the side of Center In Gdynia and GCT);

10. st. Hutnicza (from Rumia);

11. st. Morska (from Gdynia Chylonia);

12. Kwiatkowskiego wharf (from Tri-City Ring Road);

13. st. Morska (from Center of Gdynia).

Estimated transit time was set for 1800s-3600s, as traffic data obtained from the Roads and greenways management in Gdynia for traffic were presented in hourly terms. Distribution of vehicle traffic throughout the network is shown in Table 1. On this basis, the vehicle's general structure and traffic volume are determined. For the variant where the simulation will be performed for all vehicle types, the data is shown in Table 1. Percentage is in the last column.

Table 1. Intensity and percentage of all vehicles in the road network on Kwiatkowski Wharf

\begin{tabular}{|c|c|c|c|c|}
\hline Number & Section & Intensity & Uses. cars \% & Uses trucks. \% \\
\hline 1 & 37 & 650 & 85 & 15 \\
\hline 2 & 40 & 150 & 100 & 0 \\
\hline 3 & 80 & 1000 & 85 & 15 \\
\hline 4 & 8 & 550 & 82 & 18 \\
\hline 5 & 57 & 200 & 0 & 100 \\
\hline 6 & 88 & 550 & 88 & 12 \\
\hline 7 & 67 & 20 & 0 & 100 \\
\hline 8 & 30 & 50 & 0 & 100 \\
\hline 9 & 24 & 1750 & 90 & 10 \\
\hline 10 & 15 & 500 & 90 & 10 \\
\hline 11 & 4 & 1200 & 88 & 12 \\
\hline 12 & 3 & 600 & 58 & 42 \\
\hline 13 & 5 & 2100 & 98 & 2 \\
\hline
\end{tabular}

It can be seen that on average the most common dependency: $85 \%$ cars, $15 \%$ trucks.

Table 2 shows the case where trucks were removed from the grid. The last column included a $100 \%$ share of cars and bicycles in the generator at 14 .

The rates were converted in such a way as to create the actual number of passenger vehicles on the network. 
Table 2. Intensity and percentage of passenger vehicles in the road network on Kwiatkowski Wharf.

\begin{tabular}{|c|c|c|c|c|}
\hline Number & Section & Intensity & Uses cars \% & Uses trucks \% \\
\hline 1 & 37 & 550 & 100 & 0 \\
\hline 2 & 40 & 150 & 100 & 0 \\
\hline 3 & 80 & 850 & 100 & 0 \\
\hline 4 & 8 & 450 & 100 & 0 \\
\hline 5 & 57 & 0 & 100 & 0 \\
\hline 6 & 88 & 450 & 100 & 0 \\
\hline 7 & 67 & 0 & 100 & 0 \\
\hline 8 & 30 & 0 & 100 & 0 \\
\hline 9 & 24 & 1600 & 100 & 0 \\
\hline 10 & 15 & 450 & 100 & 0 \\
\hline 11 & 4 & 1050 & 100 & 0 \\
\hline 12 & 3 & 350 & 100 & 0 \\
\hline 13 & 5 & 2050 & 100 & 0 \\
\hline
\end{tabular}

The tables above show that, on average, heavy transport represents $11.82 \%$ of the number of vehicles. This is based on the actual data obtained, based on which it is assumed that 9050 vehicles will be completely through the network, of which 1070 are trucks (for two measurement hours).

\section{Analysis of simulation results}

Transit times and delays are divided into those obtained from the Estacada-Dąbka report (including other traffic flows from other traffic generators) and those obtained from the Janek Wiśniewski-Dąbka report. This passage time is measured from 1800 seconds to 3600 seconds of simulation.

Results of analysis of data obtained from the simulation model are presented in Figures 1 and 2 and in Tables 3-6.

Table 3. Average travel times and delays on the Janka Wiśniewskiego-Dąba route for all types of vehicles.

\begin{tabular}{|c|c|c|}
\hline Patameter & Travel & Delay \\
\hline Average & 1725,8 & 1669,8 \\
\hline \multicolumn{2}{|c|}{ Source: Own study }
\end{tabular}

Table 4. Average travel times and delays on the Janka Wiśniewskiego-Dąbka route for passenger cars.

\begin{tabular}{|c|c|c|}
\hline Patameter & Travel & Delay \\
\hline Average & 1383,25 & 1325,95 \\
\hline
\end{tabular}


The use of a simulation model to analyze the impact of heavy transport ... Wykorzystanie modelu symulacyjnego do analizy wplywu transportu...

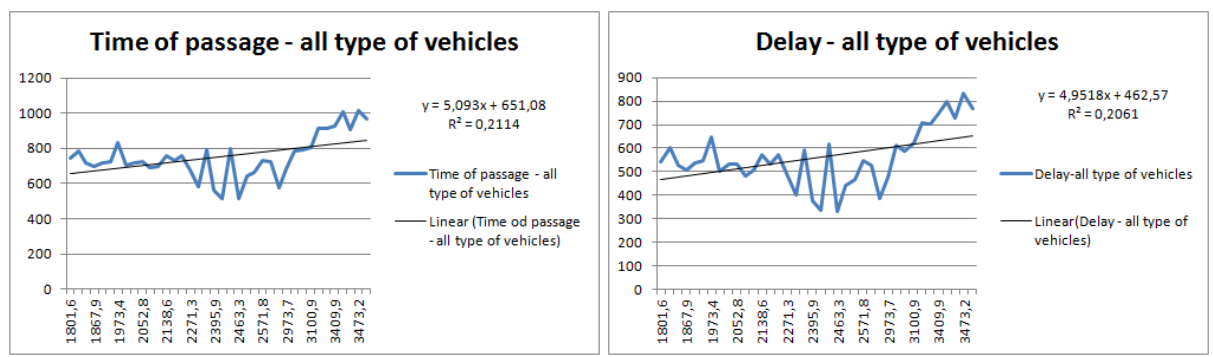

Fig. 1 Travel time (left) and delays(right) for all vehicle types for Kwiatkowski's Viaduct from the Tri-City Ring Road-Dabka (Source: Own study)

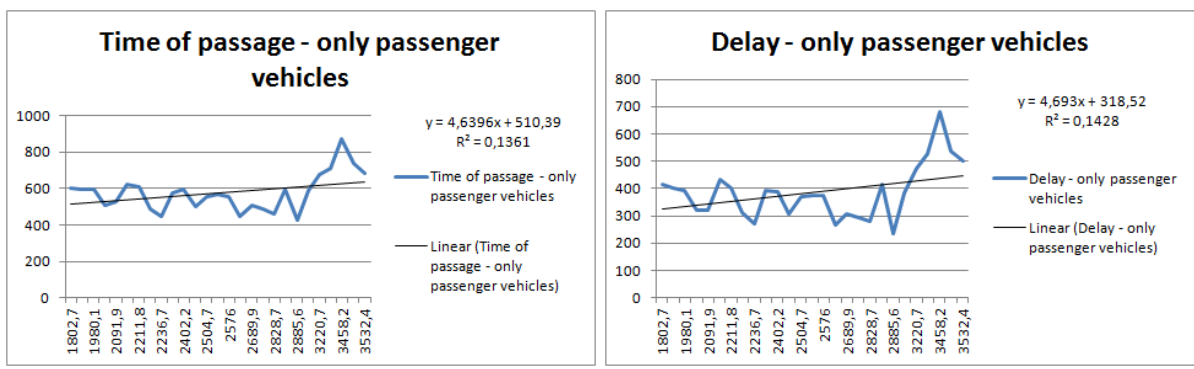

Fig. 2 Travel time (left) and delays(right) for passenger cars for Kwiatkowski's Viaduct from the Tri-City Ring Road - Dabka. (Source: Own study)

Comparing the transit times for all vehicle types and delays as well as the transit time for passenger cars along with delays you will notice that in the 1800s. Measurement has already seen the difference in passage times, this tendency has remained throughout the measurement, as has been the case with delays - the fewer lorries the lesser the delay. The fastest passage of passenger cars took place in 57 minutes of simulation and reached 870 seconds - after crossing this threshold, the journey time begins to shorten. For comparison, the fastest transit time for all types of vehicles occurred, similarly in 56 minutes, and amounted to 1010 seconds on the same route. It is worth noting that after the simulation for both variants, on average the network consisted of 882-980 vehicles.

Average journey time and delays on the Estacada-Dąbka route for passenger cars were respectively 576s. And 384s., While for all types of vehicles the average journey time was 750s. And the average delay was 559s.The graph clearly shows that the time of passing passenger cars on the same route is shorter than the time of passing all types of vehicles, which confirms the impact of heavy transport on the traffic on Kwiatkowski Wharf. The whole simulation is based on the interdependence between generators, routes through this sometimes passage. The time period considered is the peak period, and the bus traffic here is also high. 
Due to the measurements, the length of the queues (by average waiting time) was estimated for the sensitive places in three locations: 1) Exit from the wharf towards BCT and GCT ports; 2) Maritime Street from the Center; 3) Morska Street from the Rumia side.

Results for all vehicles and for passenger cars only are shown in Table 5 and Table 6. The average length of queues is in the fourth column and the maximum queue length is in the fifth column.

Table 5. Average and maximum time for all vehicle types.

\begin{tabular}{|c|c|c|c|c|}
\hline Parameter & $\begin{array}{c}\text { Observation } \\
\text { time [s]. }\end{array}$ & $\begin{array}{c}\text { Measuring } \\
\text { point }\end{array}$ & $\begin{array}{c}\text { Average transit } \\
\text { time }\end{array}$ & $\begin{array}{c}\text { Max travel } \\
\text { time }\end{array}$ \\
\hline Average & $1800-3600$ & 1 & 490,07 & 510,21 \\
\hline Average & $1800-3600$ & 2 & 191,48 & 197,96 \\
\hline Average & $1800-3600$ & 3 & 208,08 & 213,77 \\
\hline \multicolumn{2}{|r|r|}{ Source: Own study }
\end{tabular}

Table 6. Average and maximum time for passenger cars.

\begin{tabular}{|c|c|c|c|c|}
\hline Parameter & $\begin{array}{c}\text { Observation } \\
\text { time [s]. }\end{array}$ & $\begin{array}{c}\text { Measuring } \\
\text { point }\end{array}$ & $\begin{array}{c}\text { Average transit } \\
\text { time }\end{array}$ & $\begin{array}{c}\text { Max travel } \\
\text { time }\end{array}$ \\
\hline Average & $1800-3600$ & 1 & 487,61 & 510,21 \\
\hline Average & $1800-3600$ & 2 & 191,58 & 199,56 \\
\hline Average & $1800-3600$ & 3 & 207,62 & 214,68 \\
\hline
\end{tabular}

The shortest time in passenger cars was recorded in 48 minutes and amounted to 428 seconds, while the passage of all types of cars was observed in 48 minutes 518 seconds. In addition, Janka Wiśniewski's average passage time for passenger cars is 1384s. And for all types of vehicles 1725s. This is due to the fact that in the afternoon in Gdynia on Janka Wiśniewski is very often a large congestion. As for delays, the largest for passenger cars also took place in 57 minutes of simulation and was 681 seconds. It is worth noting that the delay is always less than the travel time. This means that the Trail of the Wharf is overloaded, though passable at peak times. Further analyzing, the greatest delay for all types of vehicles occurred, similarly in 57 minutes and amounted to 830 seconds on the same route. Statistical analysis of pass times and delays obtained from simulation tests was performed using the Statgraphics Centurion program. Statistical parameters are shown in the table below.

Table 7. Statistical parameters of delays for passenger cars in relation to Kwiatkowskiego Wharf -Dabka in the case of pure car and passenger car lane

\begin{tabular}{|l|c|c|}
\hline & Cars-delay & All-delay \\
\hline Average & 384,219 & 573,112 \\
\hline Standard deviation & 98,583 & 113,402 \\
\hline Coeff. of variation & $25,658 \%$ & $19,7871 \%$ \\
\hline Minimum & 233,7 & 333,6 \\
\hline Maximum & 681,6 & 830,9 \\
\hline Range & 447,9 & 497,3 \\
\hline Stnd. skewness & 2,29127 & 1,02046 \\
\hline Stnd. kurtosis & 1,96454 & 0,331737 \\
\hline
\end{tabular}


The use of a simulation model to analyze the impact of heavy transport ... Wykorzystanie modelu symulacyjnego do analizy wptywu transportu...

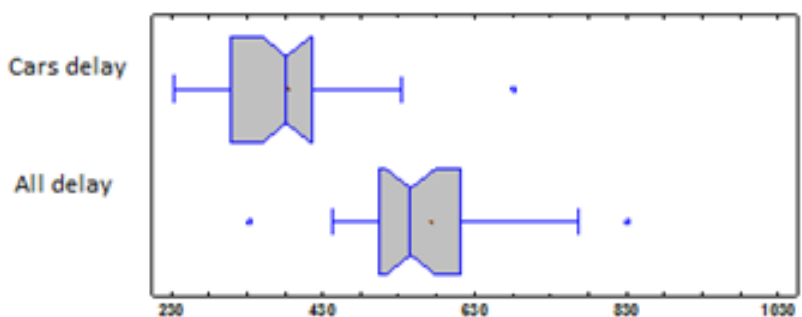

Fig.3 Box Whiskers chart for both trials (Source: Own study)

The shortest delay of passenger cars was recorded in 48 minutes, and in delay for all types of cars was observed in 41 minutes. Referring to Janka Wiśniewskiego, the average delay for the whole route for passenger cars is $1326 \mathrm{~s}$, and for all types of vehicles $1669 \mathrm{~s}$.

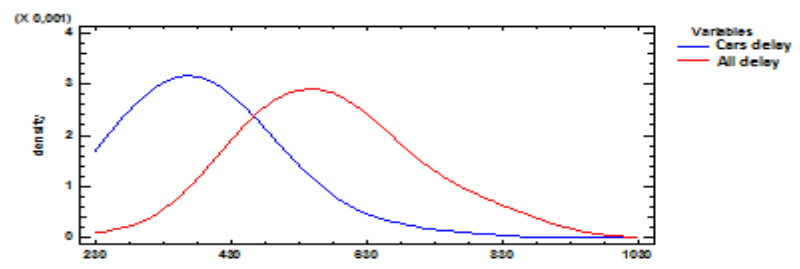

Fig. 4 Comparison of car time delays for clean car streams and streams of all vehicles (Source: Own study)

The test results for the medium and the Kolmogorov Smirnov test, as shown in Tables 8 and 9, show that the share of lorries in the traffic stream significantly influences the delay of passenger traffic at 95 significance level.

Table 8. Statistical values in the mean test

\begin{tabular}{|l|l|}
\hline \multicolumn{1}{|c|}{ T test to compare means } & \multicolumn{1}{c|}{ F-test to Compare Standard Deviations } \\
\hline Null hypothesis: mean1 = mean2 & Null hypothesis: sigma1 = sigma2 \\
\hline Alt. hypothesis: mean1 NE mean2 & Alt. hypothesis: sigma1 NE sigma2 \\
\hline $\begin{array}{l}\text { Assuming equal variances: } \\
t=-6,42311 \text { P-value }=3,06491 E-7\end{array}$ & F $=0,661527 \quad$ P-value $=0,2738$ \\
\hline $\begin{array}{l}\text { Reject the null hypothesis for } \\
\text { alpha }=0,05\end{array}$ & $\begin{array}{l}\text { Do not reject the null hypothesis for } \\
\text { alpha }=0,05 .\end{array}$ \\
\hline
\end{tabular}

(Source: Own study)

Table 9. Statistics of the K-S test

\begin{tabular}{|l|}
\hline \multicolumn{1}{|c|}{ Kolmogorov-Smirnov Test } \\
\hline Estimated overall statistic DN $=0,774815$ \\
\hline Two-sided large sample K-S statistic $=2,79157$ \\
\hline Approximate P-value $=3,40602 \mathrm{E}-7$ \\
\hline
\end{tabular}

(Source: Own study) 


\section{Summary}

On the basis of the results obtained, it can be stated that the transit time for passenger cars only (without the network of trucks) is shorter than that of all structures at once. At the afternoon peak on the Kwiatkowski route, the difference in average waiting time in the queue is statistically significantly different. Assuming that there are no ships in the GCT and BCT ports and the average daily traffic is 200 units. It is also worth noting that the model tested was designed for the peak hours of 14-16 on Friday. These are the typical hours when passenger cars increase traffic on the Kwiatkowski Route because people then return from work or go out of town. Lorry trucks are therefore rarely on the Overpass to avoid congestion. That's why most are in front of the port gates before the morning, afternoon or evening gates. This means that lorries generated by port traffic are having a moderate impact on the traffic on the Viaduct, although the expansion or construction of the Red Way would almost completely remove them from the network. In case of an increase in cargo handling at port terminals (forecasts for the next few years are very optimistic in BCT and GCT), it is also expected to increase truck traffic during peak hours, which will significantly worsen traffic conditions for passenger cars.

\section{Literature}

[1] https://pl.wikipedia.org/wiki/Trasa_im._Eugeniusza_Kwiatkowskiego, dostęp 27.11.2016

[2] Krawiec S., Celiński I. Symulacja mikroskopowa ruchu w modelu obszarowym sieci drogowej, Prace Naukowe Politechniki Warszawskiej, z. 86 Transport 2012

[3] Krystek R.i inni, Węzły drogowe i autostradowe, Wydawnictwo Komunikacji i Łączności, Warszawa 2003, s.382

[4] Bąk R., Ostrowski K., Analiza konieczności kalibracji programu Vissim w modelowaniu skrzyżowań z sygnalizacją świetlną,Logistyka 2014, nr 6

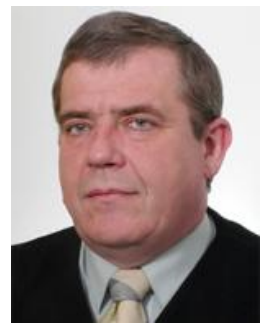

Leszek SMOLAREK Ph.D., D.Sc., Eng., Gdynia Maritime University, Gdynia, Assistant Professor at the Mathematics Department. He has 25 years experience in teaching and research work. He has published more than 30 books, reports and papers in journals and conference proceedings. Specialization: applied mathematics, reliability, statistics, and transport safety (Share 30\%).

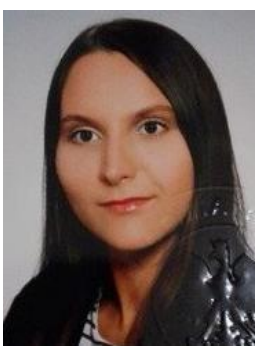

Natalia Weronika Stasiak MSc. Eng. First cycle of general academic profile in the area of technical sciences, in the field of Transport with major in Transport and Logistics, second cycle of general academic profile in the area of technical sciences, in the field of Transport with major in Maritime Transportation and Logistics Systems at the Naval Academy in Gdynia. Academic assistant at the Department of Transport and Logistics at the Gdynia Maritime Academy. Research areas: warehouse logistics, distribution logistics, traffic stream modeling, scheduling, supply chains, material flow (Share 70\%). 
The use of a simulation model to analyze the impact of heavy transport ... Wykorzystanie modelu symulacyjnego do analizy wplywu transportu...

\section{WYKORZYSTANIE MODELU SYMULACYJNEGO DO ANALIZY WPLYWU TRANSPORTU CIĘŻKIEGO GENEROWANEGO PRZEZ PORT NA RUCH MIEJSKI}

\section{Wstęp}

Estakada Kwiatkowskiego jest to trasa szybkiego ruchu w Gdyni łącząca Port Promowy i Kontenerowy, stocznię oraz bazę Marynarki Wojennej $\mathrm{z}$ obwodnicą Trójmiasta oraz $\mathrm{z}$ autostradą A1. Trasa im. Eugeniusza Kwiatkowskiego (nazywana Estakadą Kwiatkowskiego). Jest realizacją bezpośredniego połączenia obsługującego ruch ciężkich pojazdów pomiędzy rozwijającym się portem a drogami dla kołowego transportu ładunków. Jej budowana została rozpoczęta 30 sierpnia 1974 i zakończona 12 czerwca 2008. Trasa ta stanowi najdłuższy $\mathrm{i}$ dobrze dostrzegalny odcinek $\mathrm{z}$ wielu miejsc w Gdyni, [1].

Celem badań było określenie czy transport ciężki generowany przez porty w Gdyni znacznie oddziałuje na ruch na Estakadzie Kwiatkowskiego, szczególnie w godzinach zwiększonego ruchu samochodów osobowych.

Modelowany obszar dotyczył:

- dla pomiaru pierwszego, odcinka Estakady Kwiatkowskiego od strony Obwodnicy Trójmiasta do skrzyżowania na końcu Estakady Kwiatkowskiego (przed ulicą Dąbka);

- dla drugiego pomiaru, odcinka od wjazdu z ulicy Janka Wiśniewskiego do skrzyżowania na końcu Estakady Kwiatkowskiego (przed ulicą Dąbka).

W tworzonym modelu symulacyjnym uwzględniono wloty dla ruchu z kierunków od:

- Oksywia, Starego Obłuża - ul. Dąbka;

- Stoczni Marynarki Wojennej, Pogórza, BCT w Gdyni - ul. Unruga, ul. Kontenerowa;

- Stena Line w Gdyni - ul. Promowa;

- GCT - ul. Gołębia, ul. Janka Wiśniewskiego;

- Centrum - ul. Janka Wiśniewskiego, ul. Morska;

- Rumi - ul. Hutnicza;

- Gdyni Chyloni - ul. Morska;

- Obwodnicy Trójmiasta.

\section{Model symulacyjny badanego systemu}

Program Vissim służy do mikroskopowej symulacji ruchu drogowego przy modelowania ruchu. $\mathrm{Za}$ jego pomocą, możliwe jest znalezienie i przeanalizowanie różnych rozwiązań tworzenia ruchu. Mikroskopowe modele opisują oddzielnie zachowanie każdego autonomicznego pojazdu w sieci więc zarówno elementy systemu transportowego jak i interakcje zachodzące w sieci są przedstawiane bardzo szczegółowo. 
Przy pomocy programu VISSIM można przeprowadzić analizę warunków ruchu komunikacji indywidualnej oraz komunikacji zbiorowej uwzględniając takie czynniki jak wpływ przystanków autobusowych, przejścia dla pieszych, strukturę rodzajową ruchu oraz wiele innych.

Pakiet VISSIM zawiera dwa różne wewnętrzne programy: symulator ruchu oraz generator stanów sygnalizacji. Pierwszy $\mathrm{z}$ programów zbiera dane $\mathrm{z}$ detektorów i steruje sygnalizacją, a drugi jest mikroskopowym symulatorem ruchu zawierającego zasadę Wiedermana ,jazdy za liderem”, [2]. Zakłada on, że kierowcy reagują na zmiany sposobu jazdy pojazdów poprzedzających [3]. Jest to psychofizyczny model zachowania się pojazdu w ruchu opracowany przez Wiedemann'a, który zakłada, że kierujący pojazdem jadącym szybciej zaczyna hamować, kiedy osiągnie swój indywidualny próg percepcji pojazdu który porusza się wolniej. Jednakże nie jest on w stanie jednoznacznie określić prędkości tego pojazdu więc hamuje tak długo, aż jego prędkość będzie jeszcze niższa, a potem przyśpiesza. $\mathrm{W}$ konsekwencji prowadzi to do procesu hamowania i przyspieszania. Inne mniej dokładniejsze programy stosują do obliczeń stałą prędkość pojazdów [4]. Dodatkowo symulator modelu ruchu uwzględnia sytuacje takie jak np. ustąpienie pierwszeństwa dwom sąsiednim pojazdom na przyległych pasach ruchu na drodze wielopasowej, ale również zakłada, że w odległości $100 \mathrm{~m}$ od sygnalizacji świetlej uwaga kierujących jest podwyższona. Wszystkie te czynniki w połączeniu z dokładnym modelem Wiedemann'a powodują iż symulator ruchu w programie VISSIM jest bardzo dokładny.

Model Wiedemana wykorzystany w programie opisuje granicę między wyróżnionymi stanami, którymi są: jazda swobodna, zbliżanie się, jazda zależna, hamowanie. Czasy pomiaru w programie PTV VISSIM umożliwiają obliczenie czasu przepływu potoku ruchu pojazdów w zadanej konfiguracji. Aby zbadać wpływ oddziaływania transportu ciężkiego, generowanego przez porty w Gdyni na ruch na Estakadzie Kwiatkowskiego należy wziąć pod uwagę dwie opcje i je ze sobą zestawić. Mianowicie, w pierwszym wariancie przyjęto założenie, że liczony jest czas przejazdu samochodów osobowych dla przypadku udziału w ruchu samochodów ciężarowych, jak i osobowych. W drugim zaś wyłączenie udziału samochodów osobowych z Trasy Kwiatkowskiego. Jeżeli chodzi o jednostkę czasu pomiaru, założone zostały modelowo dwie godziny. Wyniki pomiarów badano jednak w odniesieniu do pół godziny, ponieważ poprzedni okres służył napełnieniu całej sieci pojazdami. Badany był piątkowy szczyt popołudniowy, godziny 14-16. Program wymagał, aby zdefiniować czasy przejazdu na sieci drogowej. Połączenia zostały wybrane w sposób taki, aby przedstawić wyniki oddziaływania pojazdów w ujęciu całościowej struktury rodzajowej (pojazdy ciężarowe i osobowe) oraz szczegółowej (tylko pojazdy osobowe) na czas transportu i występowanie kolejek. Dodatkowo symulacja została przeprowadzona w taki sposób, aby zauważyć występujące zmiany na całej sieci a nie tylko na konkretnych trasach.

W celu otrzymania danych zostały wzięte pod uwagę dwa czasy pomiarów, pozwalające na ocenę, czy transport ciężki generowany przez porty w Gdyni znacznie oddziałuje na ruch na Estakadzie Kwiatkowskiego.

Będą one oznaczane odpowiednio nr 1 oraz nr 2. Pomiar na 1 czasu przejazdu będzie się odnosił w relacji: Estakada Kwiatkowskiego (od strony Obwodnicy Trójmiasta) Skrzyżowanie na końcu Estakady Kwiatkowskiego (przed ulicą Dąbka). 
The use of a simulation model to analyze the impact of heavy transport ... Wykorzystanie modelu symulacyjnego do analizy wplywu transportu...

Drugi pomiar będzie ustawiony z ulicy Janka Wiśniewskiego do tego samego punktu, co wyżej. Pierwsza trasa została wybrana tak, aby sprawdzić ogólny czas przemieszczenia się pojazdu przez sieć, a druga trasa zawiera procentowo najwięcej samochodów ciężarowych w ujęciu całej sieci i dlatego z pewnością jej znaczenie będzie istotne.

Czas pomiaru był brany pod uwagę $\mathrm{z}$ uwzględnieniem generatorów na Trasie Kwiatkowskiego. Poszczególne numery znajdują się w pierwszej kolumnie w tabelach 1 i 2 Oznaczają one konkretne miejsca wlotów:

- ul. Dąbka (od Oksywia);

- ul. Dąbka (od Starego Obłuża);

- ul. Unruga (od Stoczni Marynarki Wojennej);

- ul. Unruga (od Pogórza);

- ul. Kontenerowa (od BCT w Gdyni);

- ul. Kontenerowa (od Pogórza);

- ul. Promowa (od Stena Line w Gdyni);

- ul. Gołębia (od GCT);

- ul. Janka Wiśniewskiego (od strony Centrum i GCT);

- ul. Hutnicza (od strony Rumi);

- ul. Morska (od strony Gdyni Chyloni);

- Estakada Kwiatkowskiego (od Obwodnicy Trójmiasta);

- ul. Morska (od Centrum).

Czas pomiaru przejazdu z założenia został ustalony na okres 1800s-3600s, ponieważ otrzymane dane z Zarządu Dróg i Zieleni dotyczących natężenia ruchu zostały przedstawione $\mathrm{w}$ ujęciu godzinowym. Rozkład natężenia ruchu pojazdów $\mathrm{w}$ całej sieci znajduje się $\mathrm{w}$ tabeli $\mathrm{nr}$ 1. Na tej podstawie ustala się strukturę rodzajową pojazdów i natężenie ruchu pojazdów. Dla wariantu, gdzie symulacja będzie przeprowadzona dla wszystkich rodzajów pojazdów, dane znajdują się w tabeli 1. Udział procentowy znajduje się w ostatnich kolumnach.

Tabela 1. Natężenie i udziat procentowy wszystkich pojazdów w sieci drogowej na Estakadzie Kwiatkowskiego. Źródto: Opracowanie własne.

\begin{tabular}{|c|c|c|c|c|}
\hline Liczba & Odcinek & Natężenie & Użytk. osob. \% & Użytk. cięż. \% \\
\hline 1 & 37 & 650 & 85 & 15 \\
\hline 2 & 40 & 150 & 100 & 0 \\
\hline 3 & 80 & 1000 & 85 & 15 \\
\hline 4 & 8 & 550 & 82 & 18 \\
\hline 5 & 57 & 200 & 0 & 100 \\
\hline 6 & 88 & 550 & 88 & 12 \\
\hline 7 & 67 & 20 & 0 & 100 \\
\hline 8 & 30 & 50 & 0 & 100 \\
\hline 9 & 24 & 1750 & 90 & 10 \\
\hline 10 & 15 & 500 & 90 & 10 \\
\hline 11 & 4 & 1200 & 88 & 12 \\
\hline 12 & 3 & 600 & 58 & 42 \\
\hline 13 & 5 & 2100 & 98 & 2 \\
\hline
\end{tabular}


Można zauważyć, że średnio występuje zależność: $85 \%$ osobowe, $15 \%$ ciężarowe. $\mathrm{W}$ tabeli 2 został przedstawiony przypadek, gdzie usunięto samochody ciężarowe z sieci. W ostatniej kolumnie znalazł się 100\% udział samochodów osobowych i rowerów w generatorze na 14 . Natężenia zostały przeliczone w sposób taki, aby powstała rzeczywista ilość pojazdów osobowych w sieci.

Tabela 2. Natężenie i udziat procentowy pojazdów osobowych $w$ sieci drogowej na Estakadzie Kwiatkowskiego. Źródto: Opracowanie własne.

\begin{tabular}{|c|c|c|c|c|}
\hline Liczba & Odcinek & Natężenie & Użytk. osob. \% & Użytk. cięż. \% \\
\hline 1 & 37 & 550 & 100 & 0 \\
\hline 2 & 40 & 150 & 100 & 0 \\
\hline 3 & 80 & 850 & 100 & 0 \\
\hline 4 & 8 & 450 & 100 & 0 \\
\hline 5 & 57 & 0 & 100 & 0 \\
\hline 6 & 88 & 450 & 100 & 0 \\
\hline 7 & 67 & 0 & 100 & 0 \\
\hline 8 & 30 & 0 & 100 & 0 \\
\hline 9 & 24 & 1600 & 100 & 0 \\
\hline 10 & 15 & 450 & 100 & 0 \\
\hline 11 & 4 & 1050 & 100 & 0 \\
\hline 12 & 3 & 350 & 100 & 0 \\
\hline 13 & 5 & 2050 & 100 & 0 \\
\hline
\end{tabular}

Z przedstawionych tabel wynika ogólnie, że przeciętnie transport ciężki stanowi $11,82 \%$ ilości pojazdów. Wynika to z uzyskanych danych rzeczywistych, na podstawie których przyjęto, że całkowicie przez sieć ma przejechać 9050 pojazdów, z czego 1070 to ciężarowe (dla dwóch godzin pomiarowych).

\section{Analiza wyników symulacji}

Czasy przejazdu oraz opóźnienia dzielą się na te uzyskane z relacji EstakadaDąbka ( $\mathrm{z}$ uwzględnieniem pozostałych potoków ruchu pojazdu $\mathrm{z}$ innych generatorów ruchu) oraz na te uzyskane z relacji Janka Wiśniewskiego - Dąbka. Ten czas przejazdu mierzony jest od 1800 sekundy do 3600 sekundy symulacji. Wyniki analizy danych uzyskanych $\mathrm{z}$ modelu symulacyjnego, zostały przedstawione na rysunkach 1 i 2 oraz się w tabelach 3-6.

Tabela 3. Uśrednione czasy przejazdu i opóźnień na trasie Janka Wiśniewskiego-Dąbka dla wszystkich typów pojazdów. Źródlo: Opracowanie własne.

\begin{tabular}{|c|c|c|}
\hline Parametr & Przejazd & Opóźnienie \\
\hline Średnia & 1725,8 & 1669,8 \\
\hline
\end{tabular}


The use of a simulation model to analyze the impact of heavy transport ... Wykorzystanie modelu symulacyjnego do analizy wplywu transportu...

Tabela 4. Uśrednione czasy przejazdu i opóźnień na trasie Janka Wiśniewskiego-Dąbka dla samochodów osobowych. Źródto: Opracowanie własne.

\begin{tabular}{|c|c|c|}
\hline Parametr & Przejazd & Opóźnienie \\
\hline Średnia & 1383,25 & 1325,95 \\
\hline
\end{tabular}
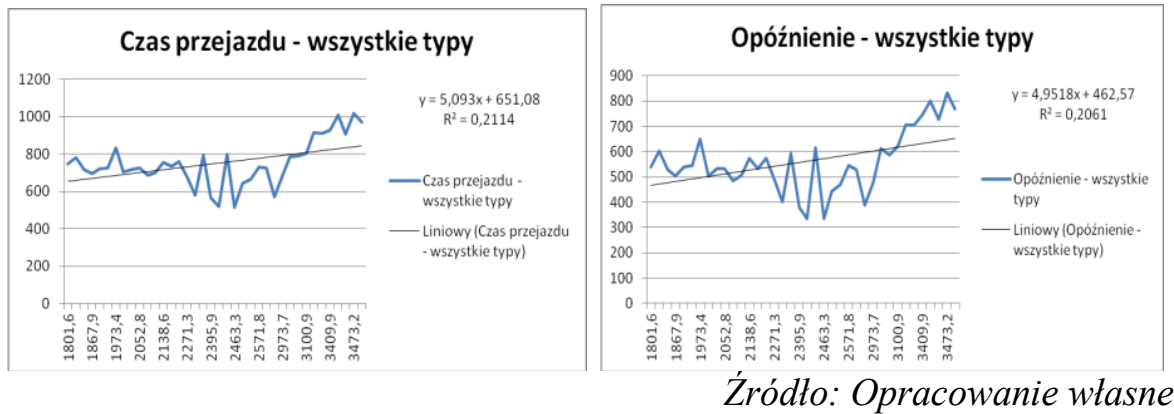

Rys.1 Czas przejazdu oraz opóźnienia dla wszystkich typów pojazdów dla Estakady Kwiatkowskiego od strony Obwodnicy Trójmiasta - Dąbka.
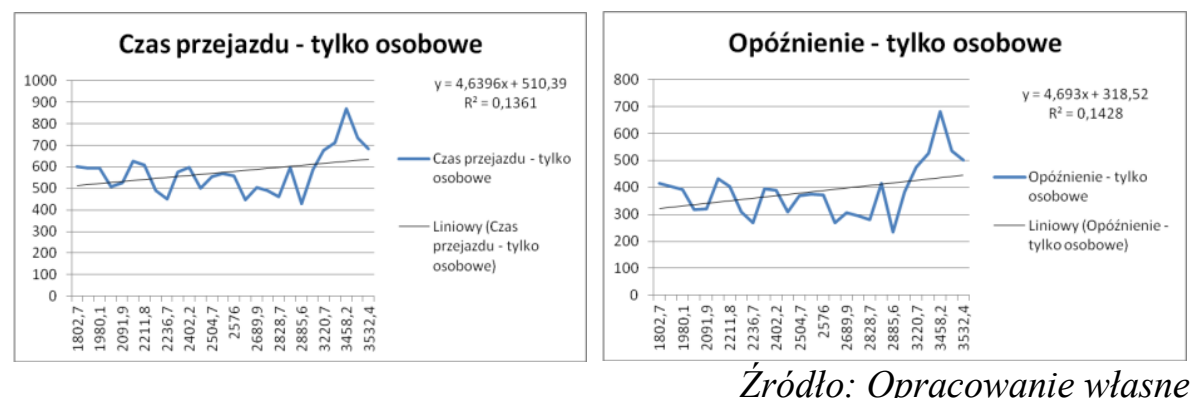

Rys. 2 Czas przejazdu oraz opóźnienia dla samochodów osobowych dla Estakady Kwiatkowskiego od strony Obwodnicy Trójmiasta - Dąbka.

Porównując czasy przejazdu dla wszystkich typów pojazdów oraz opóźnienia, jak również i czas przejazdu dla samochodów osobowych wraz z opóźnieniami można zauważyć, że w 1800 s. pomiaru już widać było różnicę w czasach przejazdu, tendencja ta utrzymywała się przez cały pomiar, podobnie jak z opóźnieniami - im mniej samochodów ciężarowych tym mniejsze opóźnienie. Największy czas przejazdu samochodów osobowych nastąpił w 57 minucie symulacji i wyniósł 870 sekund - po przekroczeniu tego progu, czas przejazdu zaczyna się skracać. Dla porównania, największy czas przejazdu dla wszystkich typów pojazdów wystąpił, podobnie w 56 minucie i wyniósł 1010 sekund na tej samej trasie. Warto dodać, że po wykonaniu symulacji dla obydwu wariantów średnio w sieci znajdowało się od 882-980 pojazdów. 
Średni czas przejazdu i opóźnień na trasie Estakada-Dąbka dla samochodów osobowych wyniósł odpowiednio: 576s. i 384s., natomiast dla wszystkich typów pojazdów średni czas przejazdu wyniósł 750s., a średnie opóźnienie 559s.

Na wykresach widać wyraźnie, że czas przejazdu samochodów osobowych na tej samej trasie jest krótszy od czasu przejazdu wszystkich typów pojazdów, co potwierdza wpływ transportu ciężkiego na ruch na Estakadzie Kwiatkowskiego. Cała symulacja opiera się na wzajemnej zależności między generatorami, trasami przez to czasami przejazdu. Rozpatrywany okres czasu jest okresem szczytowym, piątkowym w godzinach 14-16 także góruje tutaj transport samochodowy.

Dzięki przeprowadzonym pomiarom oszacowano długość kolejek (poprzez średni czas czekania) dla miejsc newralgicznych w trzech lokalizacjach:

1) Zjazd z Estakady w kierunku portów BCT i GCT;

2) Ulica Morska od strony Centrum;

3) Ulica Morska od strony Rumi.

Wyniki dla wszystkich pojazdów oraz tylko dla samochodów osobowych znajdują się w tabeli 5 oraz tabeli 6 .

Średni czas długości kolejek znajduje się w czwartej kolumnie, a maksymalny czas długości kolejki znajduje się w piątej kolumnie.

Tabela 5. Średni oraz maksymalny czas dla wszystkich typów pojazdów.

\begin{tabular}{|c|c|c|c|c|}
\hline Parametr & $\begin{array}{c}\text { Czas } \\
\text { obserwacji [s] }\end{array}$ & $\begin{array}{c}\text { Punkt } \\
\text { pomiarowy }\end{array}$ & $\begin{array}{c}\text { Średni czas } \\
\text { przejazdu }\end{array}$ & $\begin{array}{c}\text { Max czas } \\
\text { przejazdu }\end{array}$ \\
\hline Średnia & $1800-3600$ & 1 & 490,07 & 510,21 \\
\hline Średnia & $1800-3600$ & 2 & 191,48 & 197,96 \\
\hline Średnia & $1800-3600$ & 3 & 208,08 & 213,77 \\
\hline
\end{tabular}

Tabela 6. Średni oraz maksymalny czas dla samochodów osobowych.

\begin{tabular}{|c|c|c|c|c|}
\hline Parametr & $\begin{array}{c}\text { Czas } \\
\text { obserwacji [s] }\end{array}$ & $\begin{array}{c}\text { Punkt } \\
\text { pomiarowy }\end{array}$ & $\begin{array}{c}\text { Średni czas } \\
\text { przejazdu }\end{array}$ & $\begin{array}{c}\text { Max czas } \\
\text { przejazdu }\end{array}$ \\
\hline Średnia & $1800-3600$ & 1 & 487,61 & 510,21 \\
\hline Średnia & $1800-3600$ & 2 & 191,58 & 199,56 \\
\hline Średnia & $1800-3600$ & 3 & 207,62 & 214,68 \\
\hline
\end{tabular}

Źródto: Opracowanie własne

Najkrótszy czas w przejeździe samochodów osobowych odnotowany został w 48 minucie i wyniósł 428 sekund, zaś w przejeździe wszystkich typów samochodów zaobserwowano w 48 minucie czas przejazdu 518 sekund. Dodatkowo w relacji Janka Wiśniewskiego średni czas przejazdu na całej trasie dla samochodów osobowych wynosi 1384s. , a dla wszystkich typów pojazdów 1725s. Wynika to $\mathrm{z}$ faktu, że w godzinach popołudniowych w Gdyni na Janka Wiśniewskiego jest bardzo często duży zator.

Jeżeli chodzi o opóźnienia, to największe dla samochodów osobowych nastąpiło również w 57 minucie symulacji i wyniosło 681 sekund. Warto zauważyć, że opóźnienie jest zawsze mniejsze jak czas przejazdu. 
The use of a simulation model to analyze the impact of heavy transport ... Wykorzystanie modelu symulacyjnego do analizy wplywu transportu...

Oznacza to, że Trasa Estakady jest przeciążona, aczkolwiek przejezdna w godzinach szczytu. Dalej analizując, największe opóźnienie dla wszystkich typów pojazdów wystąpiło, podobnie w 57 minucie i wyniosło 830 sekund na tej samej trasie.

Analiza statystyczna czasów przejazdu i opóźnień uzyskanych $\mathrm{z}$ badań symulacyjnych została przeprowadzone przy pomocy programu Statgraphics Centurion. Parametry statystyczne przedstawia poniższa tabela.

Tabela 7. Parametry statystyczne opóźnień dla samochodów osobowych $w$ relacji Estakada-Dabka $w$ przypadku czystego strumienia samochodów osobowych $i z$ udziatem samochodów ciężarowych

\begin{tabular}{|c|c|c|}
\hline & osobowe-opozn & osobowe-all-opoz \\
\hline Average & 384,219 & 573,112 \\
\hline Standard deviation & 98,583 & 113,402 \\
\hline Coeff. of variation & $25,658 \%$ & $19,7871 \%$ \\
\hline Minimum & 233,7 & 333,6 \\
\hline Maximum & 681,6 & 830,9 \\
\hline Range & 447,9 & 497,3 \\
\hline Stnd. skewness & 2,29127 & 1,02046 \\
\hline Stnd. kurtosis & 1,96454 & 0,331737 \\
\hline
\end{tabular}

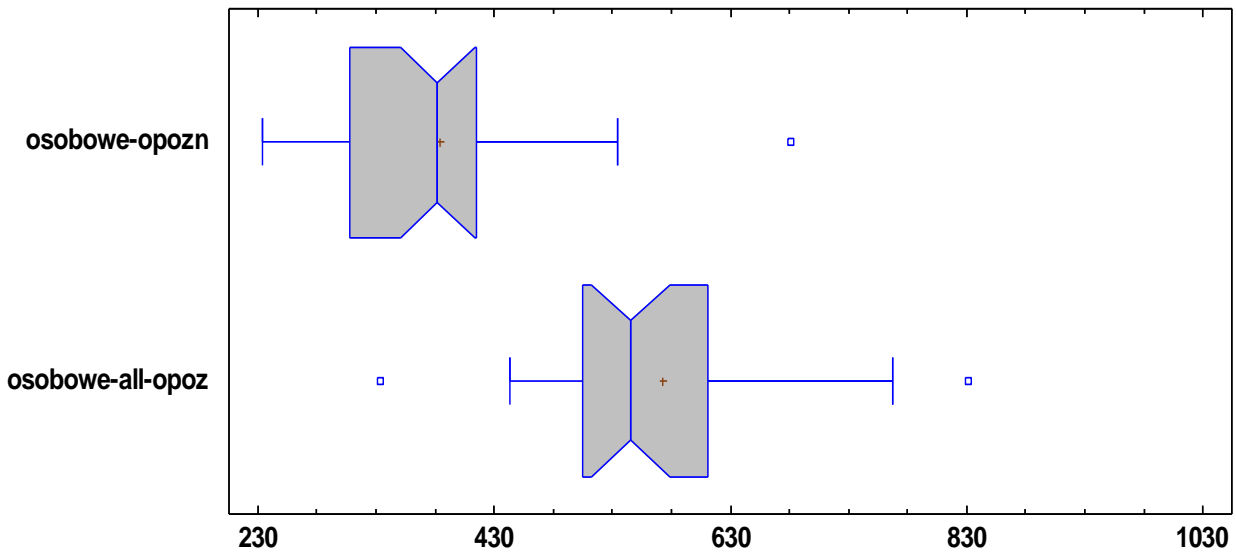

Rys. 3 Wykres Box'a Whiskersa dla obu prób

Najkrótsze opóźnienie samochodów osobowych odnotowane zostało w 48 minucie, zaś w opóźnieniu dla wszystkich typów samochodów zaobserwowano w 41 minucie. Odnosząc się do Janka Wiśniewskiego, średnie opóźnienie na całej trasie dla samochodów osobowych wynosi 1326s, a dla wszystkich typów pojazdów $1669 \mathrm{~s}$. 


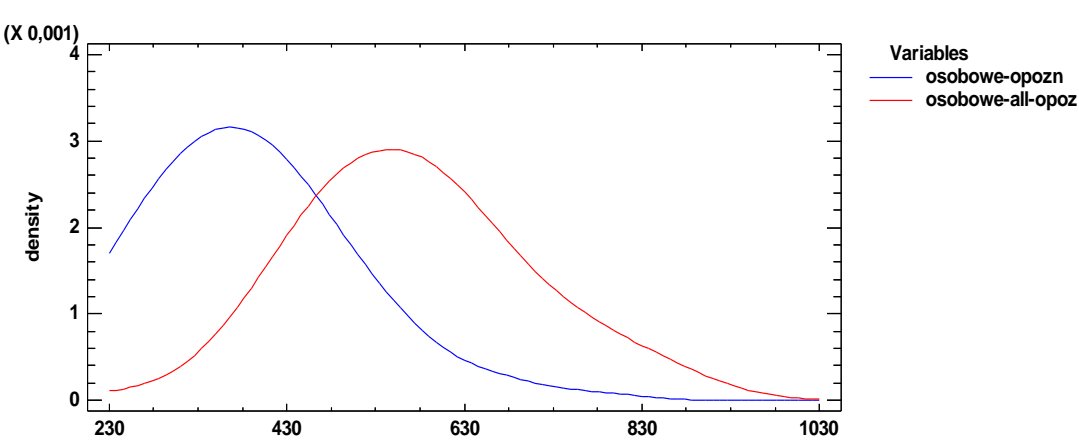

Rys. 4 Porównanie gęstości czasu opóźnień samochodów osobowych dla czystego strumienia samochodów osobowych i dla strumienia wszystkich pojazdów

Wyniki testu dla średnich oraz testu Kołmogorowa Smirnowa zgodności rozkładów, przedstawione w tabelach 8 i 9 wskazują, że udział samochodów ciężarowych w strumieni ruchu istotnie wpływa na opóźnienie ruchu pojazdów osobowych na 95 poziomie istotności.

Tabela 8. Wartości statystyk w teście średnich

\begin{tabular}{|c|c|}
\hline $\mathrm{t}$ test to compare means & F-test to Compare Standard Deviations \\
\hline Null hypothesis: mean1 = mean2 & Null hypothesis: sigma1 = sigma2 \\
\hline Alt. hypothesis: mean1 NE mean2 & Alt. hypothesis: sigma1 NE sigma2 \\
\hline $\begin{array}{c}\text { assuming equal variances: } \mathrm{t}=-6,42311 \\
\text { P-value }=3,06491 \mathrm{E}-7\end{array}$ & $\mathrm{~F}=0,661527 \quad$ P-value $=0,2738$ \\
\hline Reject the null hypothesis for alpha $=0,05$ & $\begin{array}{c}\text { Do not reject the null hypothesis for } \\
\text { alpha }=0,05 .\end{array}$ \\
\hline
\end{tabular}

Tabela 9. Wartości statystyk w teście K-S

\begin{tabular}{|c|}
\hline Kolmogorov-Smirnov Test \\
\hline Estimated overall statistic DN $=0,774815$ \\
\hline Two-sided large sample K-S statistic $=2,79157$ \\
\hline Approximate P-value $=3,40602 \mathrm{E}-7$ \\
\hline
\end{tabular}

\section{Podsumowanie}

$\mathrm{Na}$ podstawie uzyskanych wyników można stwierdzić, że czas przejazdu dla wyłącznie samochodów osobowych (bez udziału w sieci samochodów ciężarowych) jest krótszy niż przejazdu dla wszystkich struktur na raz. W szczycie popołudniowym na trasie Kwiatkowskiego różnica średniego czasu czekania w kolejce jest statystycznie istotnie różna. Przy założeniu, że w portach GCT i BCT nie stoi statek i średnie natężenia pojazdów na godzinę wynosi 200 sztuk. Warto także zwrócić uwagę na to, że badany model został zaprojektowany na godziny szczytu 14-16 w piątek. Są to typowe godziny, kiedy to samochody osobowe zwiększają ruch na Trasie Kwiatkowskiego, ponieważ wtedy ludzie wracają z pracy lub jadą poza miasto. Samochody ciężarowe z tego powodu rzadko poruszają się wtedy na Estakadzie, żeby unikać zatorów. 
The use of a simulation model to analyze the impact of heavy transport ... Wykorzystanie modelu symulacyjnego do analizy wplywu transportu...

Dlatego większość znajduje się przed bramami portów przed szczytem porannym, popołudniowym lub wieczorem. rannym Oznacza to, że pojazdy ciężarowe generowane przez ruch portowy oddziałują $\mathrm{w}$ średnim stopniu na ruch na Estakadzie, aczkolwiek rozbudowa lub budowa Drogi Czerwonej pozwoliłyby na prawie całkowite pozbycie się ich z sieci. W przypadku wzrostu przeładunków na terminalach portowych (prognozy, na kolejne lata, w BCT i GCT są bardzo optymistycznie), można oczekiwać także wzrostu natężenia ruchu pojazdów ciężarowych w godzinach szczytu, co istotnie pogorszy warunki ruchu dla samochodów osobowych.

\section{Literatura}

[1] https://pl.wikipedia.org/wiki/Trasa_im._Eugeniusza_Kwiatkowskiego, dostęp 27.11.2016

[2] Krawiec S., Celiński I. Symulacja mikroskopowa ruchu w modelu obszarowym sieci drogowej, Prace Naukowe Politechniki Warszawskiej, z. 86 Transport 2012

[3] Krystek R.i inni, Węzły drogowe i autostradowe, Wydawnictwo Komunikacji i Łączności, Warszawa 2003, s.382

[4] Bąk R., Ostrowski K., Analiza konieczności kalibracji programu Vissim w modelowaniu skrzyżowań z sygnalizacją świetlną,Logistyka 2014, nr 6

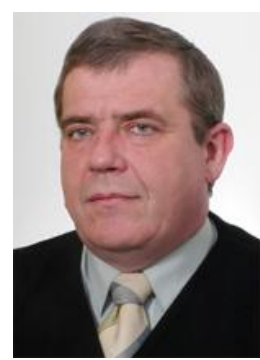

Dr hab. inz. Leszek Smolarek, prof. AMG. Kierownik Katedry Transportu i Logistyki na Wydziale Nawigacyjnym Akademii Morskiej w Gdyni. Posiada 25-letnie doświadczenie w pracy dydaktycznej i badawczej. Opublikowal ponad 30 ksiażek, raportów $i$ artykutów $w$ czasopismach $i$ materiałach konferencyjnych. Obszary badawcze: matematyka stosowana, niezawodność, statystyka i bezpieczeństwo transportu (Udziat $30 \%)$.

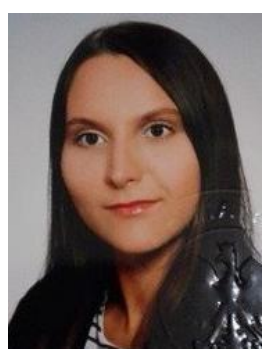

Mgr inz. Natalia Weronika Stasiak. Studia pierwszego stopnia na kierunku Transport i Logistyka, studia drugiego stopnia na kierunku Morskie Systemy Transportowe $i$ Logistyczne na Akademii Morskiej w Gdyni. Asystent naukowy $w$ Katedrze Transportu $i$ Logistyki na Akademii Morskiej w Gdyni. Obszary badawcze: logistyka magazynowa, logistyka dystrybucji, modelowanie potoków ruchu, harmonogramowanie, tańcuchy dostaw (Udziat 70\%). 